\title{
U S GEOLOGICAL SURVEY, MENLO PARK, CALIFORNIA RADIOCARBON MEASUREMENTS IV
}

\author{
DEBORAH A TRIMBLE and STEPHEN W ROBINSON \\ U S Geological Survey, Menlo Park, California 94025
}

The Menlo Park Radiocarbon Laboratory utilizes gas proportional counting of carbon dioxide in counters installed $9.5 \mathrm{~m}$ below the ground surface for background reduction (Robinson, 1977, 1979; Robinson \& Trimble, 1981, 1983). The reported results of geologic samples closely follow the guidelines of Stuiver and Polach (1977). The standard errors for analyses earlier than USGS-500 are based solely upon counting statistics, while later analyses include estimates of uncertainty in voltage, pressure, temperature, and $\delta^{13} \mathrm{C}$. Unless otherwise noted, organic samples are pretreated in $\mathrm{NaOH}$ and $\mathrm{HCl}$, and carbonate samples in $\mathrm{HCl}$.

\section{ACKNOWLEDGMENTS}

The authors gratefully acknowledge the technical assistance of Rod Mosely and John LeLange in the operation of the laboratory.

\section{United States}

Alaska

\section{Titaluk River series}

Samples coll from alluvial and lacustrine deposits exposed in a bluff $20 \mathrm{~m}$ high on Titaluk $\left(69^{\circ} 42.2^{\prime} \mathrm{N}, 155^{\circ} 12.8^{\prime} \mathrm{W}\right)$.

General Comment (LDC): dates middle Wisconsin episode of alluviation and formation of late Holocene thaw lake basin (Nelson, 1982). Coll and subm by L D Carter, USGS.

\section{USGS-628.}

Detrital peat coll $9 \mathrm{~m}$ below top of bluff.

\section{USGS-745.}

Detrital peat coll $4 \mathrm{~m}$ above base of bluff.

\section{USGS-746.}

Detrital wood coll $3 \mathrm{~m}$ above base of bluff.

\section{USGS-747.}

Detrital wood coll $1 \mathrm{~m}$ above base of bluff.
$2500 \pm 50$ $\mathbf{2 8 , 0 0 0} \pm 240$ Est $\delta^{13} C=-27 \%$ o

$43,000 \pm 1400$ Est $\delta^{13} C=-27 \%$ o

$43,000 \pm 1700$ Est $\delta^{13} C=-27 \%$ o 


\section{USGS-360. Teshekpuk Lake}

Est $\delta^{13} C=-25 \%$

Driftwood from beach deposits of fossil barrier island chain exposed in bluffs along $\mathrm{N}$ side of Teshekpuk Lake ( $\left.70^{\circ} 43^{\prime} 30^{\prime \prime} \mathrm{N}, 153^{\circ} 32^{\prime} 45^{\prime \prime} \mathrm{W}\right)$. Sample coll $4.5 \mathrm{~m}$ above base of bluff $10.6 \mathrm{~m}$ high. Comment (LDC): date suggests that islands are Sangamon in age and that little or no uplift of the coastal plain has occurred (Carter \& Robinson, 1981). Sample coll and subm by L D Carter.

\section{USGS-676. Teshekpuk Lake}

Est $\delta^{13} C=-25 \%$

Detrital peat coll $6 \mathrm{~m}$ above base of bluff $10.6 \mathrm{~m}$ high along $\mathrm{N}$ side of Teshekpuk Lake $\left(70^{\circ} 43^{\prime} 31^{\prime \prime} \mathrm{N}, 153^{\circ} 42^{\prime} 48^{\prime \prime} \mathrm{W}\right)$. Peat underlies pebbly, silty sand to sandy silt, and overlies by fossiliferous beach deposits of ancient barrier island chain (see USGS-360). Comment (LDC): sample may represent a mid-Wisconsin interstadial (Carter \& Robinson, 1981). Coll and subm by $\mathrm{L} D$ Carter.

\section{USGS-454. Harrison Bay}

$\mathbf{9 8 4 0} \pm \mathbf{9 0}$
Est $\delta^{13} C=-25 \%$

Willow (Salix sp) stump in growth position in eolian sand $2 \mathrm{~m}$ above base of coastal bluff $7.6 \mathrm{~m}$ high on Harrison Bay $\left(70^{\circ} 29^{\prime} 37.2^{\prime \prime} \mathrm{N}, 151^{\circ} 45^{\prime}\right.$ $\left.51^{\prime \prime} \mathrm{W}\right)$. Sand occurs in lee of fossil barrier island chain and overlies marine sand contemporaneous with barrier island. Comment (LDC): sand postdates last major transgression; stump is probably contemporaneous with one of woody horizons dated by USGS-377 and -378 (Robinson \& Trimble, 1983). Coll and subm by L D Carter.

USGS-455. Colville River

$>\mathbf{4 8 , 0 0 0}$

Wood fragment $7.6 \mathrm{~m}$ below top of $17.7 \mathrm{~m}$ section of Gubik Formation. Comment (LDC): sample confirms early age obtained on peat (USGS-186: $38,300 \pm 1300$, Robinson \& Trimble, 1981). Coll and subm by L D Carter.

\section{USGS-624. Kealok Creek}

$13,600 \pm 130$

Est $\delta^{13} C=-25 \%$ o

Moss coll from thin-bedded pond sand $2 \mathrm{~m}$ above base of bluff $6.7 \mathrm{~m}$ high on Kealok Creek ( $\left.70^{\circ} 18^{\prime} 24^{\prime \prime} \mathrm{N}, 153^{\circ} 26^{\prime} 21^{\prime \prime} \mathrm{W}\right)$. Comment (LDC): dates Wisconsin episode of activity of large dunes (Carter, 1983). Coll and subm by L D Carter.

\section{USGS-629. Harrison Bay}

$10,000 \pm 70$ Est $\delta^{13} C=-25 \%$ o

Peaty sand coll $1.8 \mathrm{~m}$ above base of coastal bluff $4 \mathrm{~m}$ high on Harrison Bay $\left(70^{\circ} 33^{\prime} 12^{\prime \prime} \mathrm{N}, 151^{\circ} 51^{\prime} 36^{\prime \prime} \mathrm{W}\right)$. Sample is from paleosol $10 \mathrm{~cm}$ thick, that underlies eolian sand and overlies pebbly marine or alluvial sand. Com- 
ment (LDC): date provides lower limiting age for late Wisconsinan/early Holocene episode of eolian activity. Coll and subm by L D Carter.

\section{USGS-630. Itkillik River}

$$
\text { Est } \delta^{13} C=-25 \%
$$

Detrital wood coll from alluvial deposits exposed in bluff $3.6 \mathrm{~m}$ high that forms part of $\mathrm{E}$ boundary of Itkillik R/Colville $\mathrm{R}$ flood plain $\left(70^{\circ} 09^{\prime}\right.$ $\left.29^{\prime \prime} \mathrm{N}, 150^{\circ} 48^{\prime} 21^{\prime \prime} \mathrm{W}\right)$. Sample coll $1 \mathrm{~m}$ above base of bluff. Comment (LDC): dates major terrace of the Colville R (Carter \& Galloway, 1982). Coll and subm by L D Carter.

\section{USGS-631. Colville River}

$$
\text { Est } \delta^{13} C=-25 \%
$$

Detrital wood (Picea sp) coll from alluvial deposits exposed in bluff $7 \mathrm{~m}$ high that forms part of $\mathrm{W}$ boundary of Colville $\mathrm{R}$ flood plain $\left(70^{\circ} 9^{\prime} \mathrm{N}, 151^{\circ}\right.$ $1^{\prime} 45^{\prime \prime} \mathrm{W}$ ). Sample coll $2 \mathrm{~m}$ above base of bluff. Comment (LDC): dates major terrace of Colville R (Carter \& Galloway, 1982). Coll and subm by L D Carter.

\section{USGS-675. Colville River}

$$
\text { Est } \delta^{13} C=-25 \%
$$

Detrital wood (Alnus sp) coll from alluvial deposits exposed in bluff $7.5 \mathrm{~m}$ high along Nechelik Channel of Colville R $\left(70^{\circ} 18^{\prime} 18^{\prime \prime} \mathrm{N}, 151^{\circ} 07^{\prime} \mathrm{W}\right)$. Wood coll $4.8 \mathrm{~m}$ above base of bluff. Comment (LDC): dates this bluff which forms W boundary of Colville R delta (Carter \& Galloway, 1982). Coll and subm by L D Carter.

\section{USGS-804. Titaluk River}

$\mathbf{2 8 , 7 0 0} \pm \mathbf{4 6 0}$ of horse (Equus lambei) coll with 7.6mer large mammals from surface material along base of bluff $7.6 \mathrm{~m}$ high on Titaluk R $\left(69^{\circ} 40^{\prime} 48^{\prime \prime} \mathrm{N}, 155^{\circ} 22^{\prime} \mathrm{W}\right)$. Bluff material consists of alluvium deposited when lowest alluvial terrace in this part of Titaluk $R$ valley was formed. Wood from gravel at base of bluff has been dated to $7940 \pm 130 \mathrm{BP}(\mathrm{I}-10,874)$, and wood in growth position $5 \mathrm{~m}$ above base of bluff is $8050 \pm 130 \mathrm{BP}(\mathrm{I}-10,252)$. Comment (LDC): age of horse bones indicates that bones of large mammals are being concentrated in Holocene alluvium as Titaluk $\mathrm{R}$ cuts down through Pleistocene valley fill. Coll and subm by L D Carter.

\section{USGS-414. Allen River}

$$
\text { Est } \delta^{13} C=-25 \%
$$

Detrital wood from $24 \mathrm{~m}$ bluff exposure, E side of Allen R $\left(67^{\circ} 28^{\prime} \mathrm{N}\right.$, $151^{\circ} 49^{\prime} \mathrm{W}$ ). Comment (LDC): date appears to be too old, wood may have been reworked from older deposit, or Allen $\mathrm{R}$ may have intersected fan alluvium of pre-Itkillik II age (Hamilton, 1980a). Coll and subm by T D Hamilton, USGS. 


\section{Chandalar Bluffs series}

Samples coll from $80 \mathrm{~m}$ bluff, West Fork Chandalar R $\left(67^{\circ} 12^{\prime} \mathrm{N}, 148^{\circ}\right.$ $50^{\prime} \mathrm{W}$ ).

General Comment (TDH): samples were between two tills correlated with glacial advances of Sagavanirktok R age (Hamilton, 1979, 1980a). Coll and subm by $\mathrm{T}$ D Hamilton.

\section{USGS-415.}

Detrital wood near top of bluff.

\section{USGS-416.}

Charcoal and wood from organic silt deposit beneath $0.4 \mathrm{~m}$ loess cap. Comment (TDH): may be anomalously young owing to contamination by modern rootlets and burrowing ground squirrels.

\section{Alatna River series}

Samples are from $39 \mathrm{~m}$ succession of till and outwash gravel exposed along E side of Alatna R $24 \mathrm{~km}$ below its head ( $\left.67^{\circ} 44^{\prime} \mathrm{N}, 154^{\circ} 58^{\prime} \mathrm{W}\right)$.

General Comment (TDH): originally interpreted as sediments of Itkillik II age (Hamilton \& Porter, 1975), but consistently infinite dates suggest deposit probably is older and that detrital wood and peat probably was not all reworked from earlier deposits. Restudy of exposure in 1979 revealed very sparse erratics scattered along top of bluff, implying overriding of older deposit during last glaciation (Hamilton \& Brubaker, 1983). Coll and subm by $\mathrm{T} \mathrm{D}$ Hamilton.

USGS-465.

Detrital wood.

USGS-466.

Peat clumps.

USGS-467.

Detrital wood.

USGS-468.

Bedded peat.

USGS-469.

Detrital wood.

$$
>\mathbf{5 5 , 3 0 0}
$$$$
\text { Est } \delta^{13} C=-25 \%
$$

$$
>47,300
$$$$
\text { Est } \delta^{13} C=-25 \%
$$
Est $\delta^{13} C=-25 \%$ $>42,900$ Est $\delta^{13} C=-25 \%$ $>\mathbf{5 2 , 5 0 0}$

Est $\delta^{13} C=-25 \%$ 
USGS-470.

Est $\delta^{13} C=-25 \%$

Wood and assorted plant fragments.

\section{USGS-250. Ribdon River}

$2030 \pm 120$
Est $\delta^{13} C=-25 \%$.

Peaty sand $0.5 \mathrm{~m}$ below surface in outwash terrace near head of Ribdon $\mathrm{R}\left(68^{\circ} 32^{\prime} \mathrm{N}, 148^{\circ} 03^{\prime} \mathrm{W}\right)$. Lies at contact between peat cap and Neoglacial outwash. Comment (TDH): provides min age limit on late Holocene advance of nearly cirque glacier. Coll and subm by T D Hamilton.

\section{USGS-694. Anaktuvuk River}

$$
\begin{array}{r}
13,170 \pm 70 \\
\text { Est } \delta^{13} C=-25 \% 0
\end{array}
$$

Peat and detrital organic fragments from sand between outwash deposits near mouth of Anayaknaurak Creek (68 $34^{\circ} 30^{\prime \prime} \mathrm{N}, 151^{\circ} 17^{\prime} 30^{\prime \prime}$ W). Comment (TDH): dates interstade between two glacial advances of late Wisconsin (Itkillik II) age in Anaktuvuk Valley (Hamilton, 1980b). Coll and subm by $\mathrm{T} \mathrm{D}$ Hamilton.

\section{USGS-695. Anaktuvuk River}

As described above. Check sample on USGS-694.

\section{USGS-696. Anaktuvuk Valley}

Twigs from alluvium exposed in gravel pit $1 \mathrm{~km} \mathrm{~W}$ of Tiglukpuk airstrip $\left(68^{\circ} 25^{\prime} \mathrm{N}, 151^{\circ} 29^{\prime} 30^{\prime \prime} \mathrm{W}\right)$ at $\mathrm{W}$ margin of Anaktuvuk Valley floor. Comment (TDH): dates renewed fan deposition following episode of surface stability and peat formation (Hamilton, 1980b). Coll and subm by T D Hamilton.

\section{USGS-697. Anaktuvuk Valley}

$$
\begin{array}{r}
9620 \pm \mathbf{6 0} \\
\text { Est } \delta^{13} C=-25 \% \text { o }
\end{array}
$$

Wood and peat from Tigluk gravel pit (described above). Dates $40 \mathrm{~cm}$ bed of compact black peat buried beneath $1.5 \mathrm{~m}$ fan gravel. Comment (TDH): represents early Holocene soil-forming episode (Hamilton, 1980b). Coll and subm by T D Hamilton.

\section{Lost Chicken series}

Coll in Lost Chicken gold placer mine in Fortymile $\mathrm{R}$ drainage basin $\left(64^{\circ} 3^{\prime} 48^{\prime \prime} \mathrm{N}, 141^{\circ} 53^{\prime} 48^{\prime \prime} \mathrm{W}\right)$.

General Comment (DMH): Lost Chicken Mine has yielded rich series of Pleistocene and Holocene mammalian fossils, and ${ }^{14} \mathrm{C}$ samples were coll in order to establish age and history of the faunal remains. Coll by Lee Porter and D M Hopkins; subm by D M Hopkins, USGS. 
USGS-371.

$41,000 \pm 2500$

Est $\delta^{13} C=-25 \%$

Roots and twigs hand-picked from sandy silt enclosing a caribou antler. The sandy silt and underlying gravel fill shallow bedrock channel along right side of mining pit.

USGS-372.

$$
\begin{array}{r}
\mathbf{8 6 2 0} \pm \mathbf{3 8 0} \\
\text { Est } \delta^{13} C=-25 \% \text { o }
\end{array}
$$

Log several $\mathrm{cm}$ thick and several tens of $\mathrm{cm}$ long from gravel occupying bedrock channel along left side of mining pit, ca $100 \mathrm{~m} \mathrm{~N}$ of site of USGS371. Comment $(\mathrm{DMH})$ : date and stratigraphic observations show that gravel occupies a channel incised early in Holocene time into perennially frozen silty loess and colluvium of late Wisconsin age.

USGS-370.

$\mathbf{4 1 8 0} \pm \mathbf{5 0}$
Est $\delta^{13} C=-25 \%$.

Spruce twigs from lowest forest bed exposed in Lost Chicken Mine. Forest bed is lowest in a sequence of woody layers interbedded with perennially frozen detrital peat and silty colluvium ca $5 \mathrm{~m}$ thick, and it rests on $>3 \mathrm{~m}$ of perennially frozen cross-bedded silt and sand containing a few peat lenses but no wood.

\section{USGS-384. Utukok River}

$12,410 \pm 60$

Est $\delta^{13} C=-25 \%$ o

Wood twigs from pebble gravel in terrace deposit on $\mathrm{W}$ bank of Utukok R $\left(68^{\circ} 56^{\prime} \mathrm{N}, 161^{\circ} 13^{\prime} \mathrm{W}\right)$. Sample coll ca $8 \mathrm{~m}$ below surface of terrace. Terrace is overlain by 1 to $2 \mathrm{~m}$ of silt and muck. Comment (WY): date will aid in establishing chronology of the gravel terraces and assoc glacial and marine deposits in this part of Alaska. Coll and subm by W Yeend, USGS.

\section{USGS-615. Utukok River}

$3620 \pm 140$

Est $\delta^{13} C=-25 \%$ o

Twigs from base of muck overlying terrace gravel (same location as USGS-384). Muck layer 1 to $2 \mathrm{~m}$ thick. Comment (WY): date is min for gravel deposition in this area and helps establish postglacial chronology for landscape development. Coll and subm by W Yeend.

\section{USGS-616. No Luck Lake}

$8800 \pm 70$

Est $\delta^{13} \mathrm{C}=-25 \%$ o

Wood from base of muck, S shore bank of No Luck Lake $\left(68^{\circ} 49^{\prime} \mathrm{N}\right.$, $160^{\circ} 3^{\prime} \mathrm{W}$ ). Sample coll ca $3 \mathrm{~m}$ below land surface and $2 \mathrm{~m}$ above lake level. Muck here overlies gray clay with included pebbles. Comment (WY): dates aids in establishing chronology of lake development in foothills of National Petroleum Reserve, Alaska. Coll and subm by W Yeend. 


\section{USGS-617. Colville River Bluff}

$$
\begin{array}{r}
43,700 \begin{array}{r}
+3900 \\
-2600
\end{array} \\
\text { Est } \delta^{13} C=-25 \%
\end{array}
$$

Wood from ancestral Colville R gravels (high terrace) $\left(68^{\circ} 55^{\prime} \mathrm{N}, 160^{\circ}\right.$ $20^{\prime} \mathrm{W}$ ). Sample was coll from a gravel terrace ca $50 \mathrm{~m}$ above Colville $\mathrm{R}$ and 2 to $3 \mathrm{~m}$ below top of terrace. Comment (WY): will help date ancestral Colville $\mathrm{R}$ gravels and contribute to chronology of gravel terraces in this part of Alaska. Coll and subm by W Yeend.

\section{USGS-618. Driftwood Camp Lake}

Peat from base of muck section in lake bluff $\left(68^{\circ} 55^{\prime} \mathrm{N}, 161^{\circ} 15^{\prime} \mathrm{W}\right)$. Sample was coll ca $1 \mathrm{~m}$ above lake level and $1 \mathrm{~m}$ below land surface. The muck overlies massive ice lens. Comment (WY): will help establish chronology of thaw lake development within foothills of National Petroleum Reserve, Alaska. Coll and subm by W Yeend.

\section{USGS-619. Seismo Lake}

$$
\mathbf{5 0 7 0} \pm \mathbf{9 0}
$$

Est $\delta^{13} C=-25 \%$ o

Peat enclosed by ice in lake bluff $\left(68^{\circ} 55^{\prime} \mathrm{N}, 160^{\circ} 57^{\prime} \mathrm{W}\right)$. Sample coll ca $2 \mathrm{~m}$ above lake level and $1 \mathrm{~m}$ below land surface, in section of alternating muck and ice lenses. Comment (WY): date will help establish thaw lake chronology in foothills of National Petroleum Reserve, Alaska. Coll and subm by W Yeend.

\section{Colville Delta Front Platform series}

Samples were taken within $50 \mathrm{~m}$ distance on uniformly flat platform, $5 \mathrm{~km}$ wide, at almost identical depth in central section of Colville Delta $\left(70^{\circ}\right.$ $32^{\prime} 36^{\prime \prime} \mathrm{N}, 150^{\circ} 28^{\prime} 36^{\prime \prime} \mathrm{W}$ ).

General Comment (ER): dated horizons represent first unit of fibrous organic matter in vibracores, and were thought to be correlated. The 440yr discrepancy reflects cut and fill of strudel scours, and shows there are no continuous horizons. Coll and subm by Erk Reimnitz, USGS.

USGS-575.

$$
\begin{array}{r}
\mathbf{2 9 3 0} \pm \mathbf{5 0} \\
\text { Est } \delta^{13} C=-25 \% \text { o }
\end{array}
$$

Sample at $2.0 \mathrm{~m}$ depth, $110 \mathrm{~cm}$ below sea floor, from layer of fibrous organic matter, $30 \mathrm{~cm}$ thick.

USGS-577.

$\mathbf{2 4 9 0} \pm \mathbf{5 0}$ organic matter, $5 \mathrm{~cm}$ thick.

\section{USGS-578. Simpson Lagoon, Beaufort Sea \\ $4760 \pm 100$}


corer, $100 \mathrm{~cm}$ below lagoon floor. Comment (ER): dates onset of lagoon sedimentation or transgression. Coll and subm by Erk Reimnitz.

\section{USGS-656. McKinley River}

$19,700 \pm 200$

Peaty plant fragments in organic silt in alluvium below till of last glaciation. Locality is river bluff along $\mathrm{N}$ side of McKinley $\mathrm{R}$ several $\mathrm{km} \mathrm{W}$ of Wonder Lake at $\left(63^{\circ} 26^{\prime} \mathrm{N}, 151^{\circ} 5^{\prime} \mathrm{W}\right)$. Comment (RMT): date is max limit for Wonder Lake glaciation (Hamilton, 1982). Coll and subm by R M Thorson, USGS.

\section{USGS-655. McKinley River}

$$
9580 \pm 100
$$

Wood fragments in organic silt in lake sediments just above till of last glaciation. Locality is river bluff along $\mathrm{N}$ side of McKinley $\mathrm{R}$ near Muldrow Glacier (63 $\left.26^{\prime} \mathrm{N}, 150^{\circ} 30^{\prime} 30^{\prime \prime} \mathrm{W}\right)$. Comment (RMT): date is min limit for Wonder Lake Glaciation (Hamilton, 1982). Coll and subm by R M Thorson.

\section{USGS-838. Southern Bering Sea}

$29,300 \pm 320$

Est $\delta^{13} \mathrm{C}=0 \%$ o

Marine gastropod (Neptunea heros) from $90 \mathrm{~m}$ depth in USGS core S476-G1 13. Comment (JVG): shell is from dark grayish green silty clay that is now interpreted to be glacial-period sediment deposited prior to sea-ice breakup. Coll and subm by J V Gardner and D L Kuse, USGS.

California

\section{USGS-858. Callahan Flow, Lava Beds National Monument \\ Est $\delta^{13} C=-27 \%$}

$1110 \pm 60$

Wood of tree engulfed by lava, SW corner of Lava Beds National Monument $\left(41^{\circ} 42^{\prime} \mathrm{N}, 121^{\circ} 34^{\prime} \mathrm{W}\right)$. Comment (JDN): dates one of youngest basaltic flows at Medicine Lake Volcano. Coll and subm by J DonnellyNolan, USGS.

\section{USGS-453. Northern San Francisco Bay}

$9580 \pm 70$

Freshwater peat containing achenes of Scirpus from core sample $36 \mathrm{~m}$ below msl $\left(37^{\circ} 58^{\prime} \mathrm{N}, 122^{\circ} 26^{\prime} \mathrm{W}\right)$. Comment (BA): peat probably accumulated in alluvial flood basin perhaps subject to tidal inundation during low river stages. Dates inception of widespread intertidal deposition inside Golden Gate. Age matches ( $\pm 300 \mathrm{yr}$ ) other dates on freshwater peat from comparable stratigraphic settings beneath floor of central San Francisco Bay (Atwater, Hedel \& Helley, 1977). Coll by California Div Bay Toll Crossings; subm by B Atwater and D Mann, USGS. 
USGS-493. Central San Francisco Bay

$37,500 \pm 60$ Comment (BA): date is min age for this unit because of possible contamination by younger roots. Coll by California Div Bay Toll Crossings; subm by B Atwater and B Ross, USGS.

\section{USGS-570. Bradford Island}

$42,200 \pm 1600$

Est $\delta^{13} C=-25 \%$ o

Detrital plant fragments in soft, gray, fluvial mud from auger sample $14 \mathrm{~m}$ below msl $\left(38^{\circ} 04^{\prime} \mathrm{N}, 121^{\circ} 39^{\prime} \mathrm{W}\right)$ from top of $6 \mathrm{~m}$ fining-upward sequence. Comment (BA): date is max for overlying eolian sand, which forms part of large dune field in E Contra Costa Co. Coll and subm by B Atwater.

\section{Jersey Island series}

Detrital plant fragments in interbedded gray mud and sand of fluvial origin from auger hole $\left(38^{\circ} 02^{\prime} \mathrm{N}, 121^{\circ} 40^{\prime} \mathrm{W}\right)$.

General Comment (BA): dates eposide of aggradation at this site and correlates it with fining-upward sequence at Bradford I (USGS-570). Coll and subm by B Atwater.

USGS-571.

$$
\begin{array}{r}
43,000 \pm 1700 \\
\text { Est } \delta^{13} C=-25 \% 0
\end{array}
$$

Sample from $20 \mathrm{~m}$ below msl, separated from overlying eolian sand by $10 \mathrm{~m}$ of fluvial sand. Comment (BA): date is max for dune field of E Contra Costa Co.

\section{USGS-572.}

Sample from $24 \mathrm{~m}$ below msl.

\section{USGS-665. Little Packer Lake}

Detrital wood in lacustrine mud from borehole sample 3.4 to $3.6 \mathrm{~m}$ below surface of filled oxbow lake near Sacramento R $\left(39^{\circ} 27^{\prime} \mathrm{N}, 122^{\circ} 01^{\prime}\right.$ W). Comment (BA): date is min for creation of lake. Coll by D Sullivan, D Belknap, B Atwater and subm by B Atwater.

\section{USGS-666. Little Packer Lake}

$$
\begin{array}{r}
4060 \pm 150 \\
\text { Est } \delta^{13} C=-25 \% \text {. }
\end{array}
$$

Detrital wood in lacustrine mud from borehole sample 7.8 to $8.0 \mathrm{~m}$ below surface of natural levee bordering oxbow lake of Sacramento R $\left(39^{\circ}\right.$ $\left.27^{\prime} \mathrm{N}, 122^{\circ} 01^{\prime} \mathrm{W}\right)$. Comment (BA): date is max creation of these levees. Coll by D Sullivan, D Belknap, B Atwater and subm by B Atwater. 


\section{Clear Lake, Core 3 series}

Carbonaceous sediments from Clear Lake, core $3\left(39^{\circ} 2^{\prime} 54^{\prime \prime} \mathrm{N}, 122^{\circ}\right.$ $50^{\prime} 24^{\prime \prime} \mathrm{W}$ ).

General Comment (JDS): dates sedimentation rates and events in core and assists correlations with seven other cores in lake (Sims, 1976). Coll and subm by J D Sims, USGS.

USGS-432.

Depth in core 1216 to $1223 \mathrm{~cm}$.

USGS-433.

Depth in core 4517 to $4523 \mathrm{~cm}$.

USGS-434.

Depth in core 4778 to $4783 \mathrm{~cm}$.

USGS-435.

Depth in core 5638 to $5642 \mathrm{~cm}$.

USGS-436.

Depth in core 6662 to $6668 \mathrm{~cm}$.

\section{USGS-437.}

Depth in core 6765 to $6770 \mathrm{~cm}$.
$17,600 \pm 450$ Est $\delta^{13} C=-25 \%$ o

$\mathbf{2 7 , 5 0 0} \pm \mathbf{7 0 0}$ Est $\delta^{13} C=-25 \%$ o

$28,800 \pm 640$ Est $\delta^{13} C=-25 \%$ o

$\mathbf{3 4 , 4 0 0} \pm 950$ Est $\delta^{13} C=-25 \%$ o

$29,800 \pm 1600$ Est $\delta^{13} C=-25 \%$ o

$\mathbf{2 9 , 9 0 0} \pm \mathbf{8 0 0}$ Est $\delta^{13} \mathrm{C}=-25 \%$ o

\section{Clear Lake, Core 4 series}

Carbonaceous sediment from Clear Lake, core $4\left(39^{\circ} 2^{\prime} 24^{\prime \prime} \mathrm{N}, 122^{\circ}\right.$ $\left.48^{\prime} 36^{\prime \prime} \mathrm{W}\right)$.

General Comment (JDS): dates and confirms pollen curve that is interpreted to represent an uncalibrated paleotemperature curve correlated with $\delta^{18} \mathrm{O}$ curves from deep sea. Also dates sedimentation rates and events in this core and is used to correlate with seven other cores taken from lake (Sims, 1976). Coll and subm by J D Sims.

\section{USGS-444.}

Depth in core 4005 to $4015 \mathrm{~cm}$.

\section{USGS-445.}

Depth in core 1495 to $1505 \mathrm{~cm}$. $\mathbf{2 6 , 3 5 0} \pm \mathbf{4 4 0}$

Est $\delta^{13} C=-25 \%$ o

$$
10,410 \pm 70
$$

Est $\delta^{13} C=-25 \%$ o 
USGS-446.

Depth in core 807 to $812 \mathrm{~cm}$.

USGS-447.

Depth in core 8005 to $8015 \mathrm{~cm}$.
$6930 \pm 90$

Est $\delta^{13} C=-25 \%$ o

$32,800 \pm 900$

Est $\delta^{13} C=-25 \%$ o

\section{Clear Lake, Core 6 series}

Peaty sediment from Clear Lake, core $6\left(39^{\circ} 1^{\prime} \mathrm{N}, 122^{\circ} 42^{\prime} 30^{\prime \prime} \mathrm{W}\right)$.

General Comment (JDS): dates sedimentation rates and events in core and assists in correlation with seven other cores taken from lake (Sims, 1976). Coll and subm by J D Sims.

USGS-520.

Depth in core 1835 to $1840 \mathrm{~cm}$.

USGS-521.

Depth in core 2052 to $2057 \mathrm{~cm}$.

\section{USGS-549. Three Peaks, Marin Co}

$\mathbf{2 9 , 9 0 0} \pm \mathbf{5 5 0}$ Est $\delta^{13} C=-25 \%$

$\mathbf{2 9 , 4 0 0} \pm \mathbf{5 0 0}$ Est $\delta^{13} C=-25 \%$ o

$<\mathbf{1 0 0}$

Charcoal fragments in alluvial deposits exposed in stream cut $1 \mathrm{~km} \mathrm{E}$ of Three Peaks ( $\left.38^{\circ} 8^{\prime} 15^{\prime \prime} \mathrm{N}, 122^{\circ} 46^{\prime} 45^{\prime \prime} \mathrm{W}\right)$. Charcoal occurs ca $0.5 \mathrm{~m}$ below ground surface in discontinuous bed of coarse- to medium-size sand. Dated bed is truncated by deposits interpreted to be debris flow deposits. Comment (DMP): date is max of debris flow event. Coll and subm by D M Peterson and S Ellen, USGS.

\section{USGS-550. Three Peaks, Marin Co}

$230 \pm 70$

Est $\delta^{13} C=-25 \%$ o

Charcoal fragments in alluvial deposits exposed in stream cut $1 \mathrm{~km} \mathrm{E}$ of Three Peaks ( $\left.38^{\circ} 8^{\prime} 25^{\prime \prime} \mathrm{N}, 122^{\circ} 46^{\prime} 45^{\prime \prime} \mathrm{W}\right)$. Charcoal occurs $1.6 \mathrm{~m}$ below ground surface in coarse sand lens. Comment (DMP): dated lens stratigraphically underlies deposits interpreted to be debris flow deposits, indicating max age of debris flow event. Coll and subm by D M Peterson and S Ellen, USGS.

\section{USGS-551. Alpine Lake, Marin Co}

$1550 \pm \mathbf{8 0}$
Est $\delta^{13} C=-25 \% 0$

Carbonized wood in colluvium exposed in road cut at SW end Alpine Lake $\left(37^{\circ} 56^{\prime} 15^{\prime \prime} \mathrm{N}, 122^{\circ} 38^{\prime} 15^{\prime \prime} \mathrm{N}\right)$. Wood specimen occurred ca $3 \mathrm{~m}$ below ground surface in colluvial accumulation filling uppermost segment of small drainage. Base of deposit not exposed. Total thickness is estimated to be at least $6 \mathrm{~m}$. Comment (DMP): date is min of deposit. Similar colluvial 
deposits are common through Marin Co. Apparently none of these deposits have been dated previously. Coll and subm by S Ellen and D M Peterson.

\section{Kansas}

USGS-744. Wilson Ford

$>\mathbf{5 3 , 0 0 0}$
Est $\delta^{13} \mathrm{C}=0^{\circ} \% \mathrm{O}$

Shell (right valve of Amblema plicata (Say)) from gravel unit near base of terrace exposed in E bank of Fall R ( $\left.37^{\circ} 31^{\prime} 25^{\prime \prime} \mathrm{N}, 95^{\circ} 54^{\prime} 57^{\prime \prime} \mathrm{W}\right)$. Subm as check on date M-997 (Crane \& Griffin, 1962, p 186) based on Lasimigona complanata Barnes from same unit. Original date (M-997: 31,000 \pm 6000$)$ has been used in literature as terminal date for extinction of Bison alleni, but this interpretation has been questioned by Robinson (1981). Coll July 1947 by C Carpenter and C W Hibbard; subm by B B Miller, Kent State Univ.

Washington

USGS-782. Big Lake

$13,370 \pm 70$

Est $\delta^{13} \mathrm{C}=0^{\%} \%$

Marine shell fragments from gray silts at NW end of Big Lake $\left(48^{\circ} 23^{\prime}\right.$ $\left.30^{\prime \prime} \mathrm{N}, 122^{\circ} 14^{\prime} 30^{\prime \prime} \mathrm{W}\right), 23 \mathrm{~m}$ above present sea level, overlying glaciomarine drift. Comment (DD): dates later Pleistocene marine incursion during deglaciation of NW Washington. Coll by J Minard and subm by $\mathrm{D}$ Dethier, USGS.

\section{USGS-787. Big Lake}

$13,040 \pm 70$

Est $\delta^{13} \mathrm{C}=0 \%$

Marine shells in growth position from silty sand which overlies Vashon till $24 \mathrm{~m}$ above present sea level at SE end of Big Lake $\left(48^{\circ} 22^{\prime} \mathrm{N}, 122^{\circ} 13^{\prime}\right.$ W). Comment (DD): dates later Pleistocene marine incursion during deglaciation of NW Washington. Coll and subm by D Dethier.

\section{USGS-881. Gilligan Creek}

$\mathbf{3 6 0 0} \pm \mathbf{5 0}$

Outer wood of $\log$ from sand and gravel exposure at ca $40 \mathrm{~m}$ elev near mouth of Gilligan Creek ( $\left.48^{\circ} 29^{\prime} \mathrm{N}, 122^{\circ} 8^{\prime} \mathrm{W}\right)$. Comment (DD): dates construction of alluvial fan by Gilligan Creek into Skagit Valley. Coll and subm by $\mathrm{D}$ Dethier.

\section{USGS-905. Concrete East}

$1860 \pm 180$

Log in laminated silt and sand underlying ca $50 \mathrm{~m}$ coarse gravel capped by till at ca $60 \mathrm{~m}$ elev, $1 \mathrm{~km} \mathrm{SE}$ of Concrete $\left(48^{\circ} 32^{\prime} \mathrm{N}, 121^{\circ} 44^{\prime} \mathrm{W}\right)$. Comment (DD): date is max limit for advance of Cordilleran ice up Skagit Valley. Coll and subm by D Dethier. 
USGS-963. Freeland

Est $\delta^{13} C=-27 \%$

Charcoal in sand rich in pumice lapilli, underlying ca $4 \mathrm{~m}$ of Vashon Drift, at ca $40 \mathrm{~m}$ elev, $2.5 \mathrm{~km} \mathrm{NW}$ of Freeland $\left(48^{\circ} 01^{\prime} 30^{\prime \prime} \mathrm{N}, 122^{\circ} 33^{\prime} \mathrm{W}\right)$. Comment (DD): date is min limit for deposition of dacite-rich alluvium derived from Glacier Peak. Coll and subm by D Dethier.

\section{USGS-967. Salkum}

$$
\begin{array}{r}
\mathbf{5 3 , 0 0 0} \begin{array}{r}
+\mathbf{3 0 0 0} \\
-\mathbf{2 2 0 0}
\end{array} \\
\text { Est } \delta^{13} C=-27 \% 0
\end{array}
$$

Compressed wood in medium sand and silt, with pumice lapilli, underlying 5 to $10 \mathrm{~m}$ of volcanic-rich alluvium capped by Evans Creek outwash. Coll $3 \mathrm{~km} \mathrm{SW}$ of Salkum, Washington $\left(46^{\circ} 30^{\prime} \mathrm{N}, 122^{\circ} 38^{\prime} 30^{\prime \prime} \mathrm{W}\right)$ at ca $80 \mathrm{~m}$ elev on N bank of Cowlitz R. Comment (DD): dates laharic fill of Cowlitz $\mathrm{R}$ during pre-Evans Creek eruption at Mount Rainier. Coll and sub by D Dethier.

\section{USGS-864. Mundt Creek}

Est $\delta^{13} C=-27 \%$

Wood fragment from locally derived pebbly silt which directly underlies Vashon till $5 \mathrm{~km} \mathrm{SE}$ of Clear Lake (48 $\left.27^{\prime} 30^{\prime \prime} \mathrm{N}, 122^{\circ} 11^{\prime} \mathrm{W}\right)$. Comment (DD): dates period of landslides and fan construction as Vashon ice thinned, but before marine incursion in this area. Coll and subm by D Dethier.

\section{USGS-865. Cicero}

$$
8420 \pm 90
$$

Charcoal fragments in pumice-rich lahar which directly overlies Vashon recessional outwash $2 \mathrm{~km} \mathrm{~N}$ of Cicero $\left(48^{\circ} 17^{\prime} \mathrm{N}, 122^{\circ} 1^{\prime} 30^{\prime \prime} \mathrm{W}\right)$ at ca $85 \mathrm{~m}$ elev. Comment (DD): young apparent age suggests charcoal is younger than lahar, or was contaminated. Coll and subm by D Dethier.

\section{USGS-866. Collins Road, Sterling}

$\mathbf{1 7 9 0} \pm \mathbf{8 0}$
Est $\delta^{13} \mathrm{C}=-27 \% 0$

Charcoal fragments in gray silt interbedded with sand and pumice lapilli derived from Glacier Peak. Sample coll along Collins Road $\left(48^{\circ} 29^{\prime}\right.$ $\left.30^{\prime \prime} \mathrm{N}, 122^{\circ} 17^{\prime} \mathrm{W}\right)$. Comment (DD): dates late Holocene influx of volcanic debris from Glacier Peak, and formation of terrace deposit, $>10 \mathrm{~m}$ thick. Coll and subm by D Dethier.

\section{USGS-879. Gilligan Creek East}

$2180 \pm 50$

Wood $(\log )$ in locally derived fine sand and silt underlying ca $1 \mathrm{~m}$ oxidized sand and gravel $1 \mathrm{~km} \mathrm{E}$ of Gilligan Creek $\left(48^{\circ} 29^{\prime} 30^{\prime \prime} \mathrm{N}, 122^{\circ} 7^{\prime} \mathrm{W}\right)$, at ca $28 \mathrm{~m}$ elev. Comment (DD): dates deposition of broad alluvial fan complex into Skagit Valley. Coll and subm by D Dethier. 


\section{USGS-880. Day Creek}

$4790 \pm 80$

Charcoal fragments from medium sand with pumice lapilli underlying $80 \mathrm{~cm}$ massive silt and overlying $>150 \mathrm{~cm}$ oxidized sand and gravel at ca $25 \mathrm{~m}$ elev, $2 \mathrm{~km}$ NW of Day Creek $\left(48^{\circ} 30^{\prime} \mathrm{N}, 122^{\circ} 5^{\prime} \mathrm{W}\right)$. Comment (DD): dates influx of laharic debris from Glacier Peak and formation of midHolocene fill terrace. Coll and subm by D Dethier.

\section{USGS-766. Tulalip Creek Valley}

$$
\begin{aligned}
& \begin{array}{r}
47,200+2600 \\
-1900
\end{array} \\
& \text { Est } \delta^{13} C=-27 \% \text { o }
\end{aligned}
$$

Compressed peat layer in thick bedded sand below Vashon advance outwash, 30 to $40 \mathrm{~m}$ below Vashon till $\left(48^{\circ} 05^{\prime} 45^{\prime \prime} \mathrm{N}, 122^{\circ} 16^{\prime} 26^{\prime \prime} \mathrm{W}\right)$. Comment (JM): provides age control on Esperance advance outwash. Coll and subm by J Minard, USGS.

\section{USGS-765. Stillaguamish River Valley}

$23,700 \pm 210$

Est $\delta^{13} C=-27 \%$ o

Compressed peat layer in lower advance outwash or pre-advance outwash bedded silt and sand 3 to $4 \mathrm{~m}$ below base of Vashon till $\left(48^{\circ} 12^{\prime} 5^{\prime \prime} \mathrm{N}\right.$, $\left.122^{\circ} 11^{\prime} 52^{\prime \prime} \mathrm{W}\right)$. Comment (JM): provides age control on known stratigraphic section. Coll and subm by J Minard.

\section{USGS-767. Stillaguamish River Valley}

$28,000 \pm 160$ Est $\delta^{13} C=-27 \%$ o

Compressed peat layer in thick lower advance outwash or pre-advance outwash sediment 2 to $3 \mathrm{~m}$ below base of Vashon till $\left(48^{\circ} 12^{\prime} 23^{\prime \prime} \mathrm{N}, 122^{\circ} 09^{\prime}\right.$ $\left.04^{\prime} \mathrm{W}\right)$. Comment ( JM): dates recessional sequence and relation to Vashon till. Coll and subm by J Minard.

\section{USGS-768. Snohomish River Valley}

$$
\text { Est } \delta^{13} C=-27 \%
$$

Sample from roadcut along Hwy 2 just W of Westwick Rd $\left(47^{\circ} 54^{\prime} 23^{\prime \prime}\right.$ $\mathrm{N}, 122^{\circ} 2^{\prime} 36^{\prime \prime} \mathrm{W}$ ). Compact peat and flattened plant stems bedded in fine sand and silt in pre-Vashon-advanced outwash sediments 1 to $2 \mathrm{~m}$ below Vashon till. Comment (JM): allows age correlation with advance outwash to $\mathrm{W}$ and E. Coll and subm by J Minard.

\section{USGS-770. Stillaguamish River Valley}

$39,700 \pm 1100$

Est $\delta^{13} C=-27 \%$ o

Layer of wood-lignite in base of interbedded sand, silt, and clay in Stanwood Water Well roadcut $\left(48^{\circ} 12^{\prime} 28^{\prime \prime} \mathrm{N}, 122^{\circ} 19^{\prime} 55^{\prime \prime} \mathrm{W}\right)$. Sample is just above oxidized possible Olympia interglacial gravel $70 \mathrm{~m}$ below Vashon till. Comment (JM): provides age control in area. Coll and subm by $\mathrm{J}$ Minard. 
USGS-771. Silvana Terraces

Est $\delta^{13} C=\begin{array}{r}>49,000 \\ =\end{array}$

Brown to black compact peat $1 \mathrm{~m}$ above glacial marine drift and below section of till and bedded sediments on bank of Stillaguamish R $\left(48^{\circ} 12^{\prime} 17^{\prime \prime}\right.$ $\left.\mathrm{N}, 122^{\circ} 17^{\prime} 56^{\prime \prime} \mathrm{W}\right)$. Comment ( JM): dates fossiliferous glacial marine drift. Coll and subm by J Minard.

\section{USGS-877. Silvana Terraces}

46,500 \pm 1110

Est $\delta^{13} \mathrm{C}=0 \%$ o

Pelecypod shell material in glacial marine drift $1 \mathrm{~m}$ below peat of USGS-771. Dates fossiliferous glacial marine drift. Coll and subm by $\mathrm{J}$ Minard.

\section{USGS-772. Pilchuck Creek Valley}

$\mathbf{2 4 , 7 0 0} \pm \mathbf{1 6 0}$

Flattened plant stems, twigs, and branches in clay beneath $25 \mathrm{~m}$ plus of bedded Vashon advance outwash and pre-Vashon sedments. Sample from $\mathrm{N}$ side of Pilchuck Creek Valley $\left(48^{\circ} 14^{\prime} 18^{\prime \prime} \mathrm{N}, 122^{\circ} 12^{\prime} 26^{\prime \prime} \mathrm{W}\right)$. Comment ( JM): date extends known date line near $\mathrm{E}$ limit of continental ice lake. Coll and subm by J Minard.

\section{USGS-808. Marysville}

$13,300 \pm 60$

Pelecypod shells (many in feeding position) near base of $6 \mathrm{~m}$ of tidal flat muck, directly on Vashon till. Sample coll on Hickok Road $\left(48^{\circ} 3^{\prime} 13^{\prime \prime} \mathrm{N}\right.$, $\left.122^{\circ} 9^{\prime} 8^{\prime \prime} \mathrm{W}\right)$. Comment (JM): dates withdrawal of ice from area. Coll and subm by J Minard.

\section{USGS-773. Lower North Creek Valley}

$$
\begin{aligned}
& \mathbf{4 9 , 9 0 0}+\mathbf{3 3 0 0} \\
& \text { Est } \delta^{13} C=-27 \% \text { o }
\end{aligned}
$$

Single piece of flattened wood in slit layers in bedded pre-Vashon sand NW of Woodinville $\left(47^{\circ} 46^{\prime} \mathrm{N}, 122^{\circ} 10^{\prime} 25 \mathrm{~W}\right)$. Comment (JM): date helps understanding of times and rates of ice advance in area. Sample is possibly redeposited. Coll and subm by J Minard.

\section{REFERENCES}

Atwater, B F, Hedel, C W and Helley, E J, 1977, Late Quaternary depositional history, Holocene sea-level changes, and vertical crustal movement, southern San Francisco Bay, California: USGS Prof Paper 1014, 15 p.

Carter, L D, 1983, Fossil sand wedges on the Alaskan Arctic Coastal Plain and their paleoenvironmental significance, in Internatl conf on permafrost, 4th, Fairbanks, Univ Alaska, Proc: Washington, D C, Natl Acad Press, p 109-114.

Carter, L D and Galloway, J P, 1982, Terraces of the Colville River Delta region, Alaska, in Coonrad, W L, eds, The U S Geological Survey Alaska: Accomplishments during 1980: USGS circular 884, p 49-51.

Carter, L D and Robinson, S W, 1981, Minimum age of beach deposits north of Teshekpuk Lake, Alaskan Arctic coastal plain, in Albert, N R D and Hudson, T, eds, The USGS in Alaska: Accomplishments during 1979: U S G S circular 823-b, p B8-B9.

Crane, H R and Griffin, J B, 1962, University of Michigan radiocarbon dates VII: Radiocarbon, $v$ 4, p 183-203. 
Hamilton, T D, 1979, Quaternary stratigraphic sections with radiocarbon dates, Chandalar quadrangle, Alaska: USGS open-file rept 79-751, $10 \mathrm{p}$.

_ _ 1980a, Quaternary stratigraphic sections with radiocarbon dates with Wiseman quadrangle, Alaska: USGS open-file rept 80-791, $53 \mathrm{p}$.

1980b, Quaternary stratigraphic sections with radiocarbon dates Chandler Lake quadrangle, Alaska: USGS open-file rept 80-79, $28 \mathrm{p}$

- 1982, A late Pleistocene glacial chronology for the southern Brooks Range; stratigraphic record and regional significance: Geol Soc America Bull, v 93, no. 8, p 700716.

Hamilton, T D and Brubaker, L B, 1983, Quaternary stratigraphic sections with radiocarbon dates, Survey Pass quadrangle, Alaska: USGS open-file rept 83-72, $47 \mathrm{p}$.

Hamilton, T D and Porter, S C, 1975, Itkillik glaciation in the Brooks Range, northern Alaska: Quaternary Research, v 5, no. 4, p 471-497.

Nelson, R E, (ms) 1982, Late Quaternary environments of the western arctic slope of Alaska: PhD dissert, Univ Washington, Seattle.

Robinson, S W, 1977, U S Geological Survey, Menlo Park, California, radiocarbon measurements I: Radiocarbon, v 19, no. 3, p 460-464.

1979, Radiocarbon dating at the USGS, Menlo Park, California, in Berger, R, and Suess, $\mathrm{H}$ E, eds, Radiocarbon dating, Internatl ${ }^{14} \mathrm{C}$ conf, 9 th, Proc: Berkeley, Univ California Press, p 268-273.

1981, Comment on, A radiocarbon-dated (Wisconsinan) molluscan fauna from southeastern Kansas, by B B Miller: Jour Paleontology, v 55, p 271-272.

Robinson, S W and Trimble, D A, 1981, U S Geological Survey, Menlo Park, California radiocarbon measurements II: Radiocarbon, v 23, no. 2, p 305-321.

1983, U S Geological Survey, Menlo Park, California radiocarbon measurements III: Radiocarbon, v 25, no. 1, p 143-151.

Sims, J D, 1976, Paleolimnology of Clear Lake, California, USA, in Horie, S, ed, Paleolimnology of Lake Biwa and the Japanese Pleistocene: Univ Kyoto, v 4, p 648-702.

Stuiver, $M$ and Polach, H A, 1977, Discussion: Reporting of ${ }^{14} \mathrm{C}$ data: Radiocarbon, v 19, no. 3 , p 335-363. 